\title{
VALUING SOIL CONSERVATION PRACTICES USING CONTINGENT VALUATION TECHNIQUE: EVIDENCE FROM THE CENTRAL RIFT VALLEY OF ETHIOPIA
}

\author{
Musa H. AHMED*, Kumilachew A. MELESSE, Aemro T. TEREFE
}

\author{
Address: \\ Haramaya University, P O Box 95, Dire Dawa, Ethiopia \\ *Corresponding author, e-mail: musa.hassen@haramaya.edu.et
}

\begin{abstract}
Land degradation mainly in the form of soil and nutrient depletion is the prominent problem that the Ethiopian agriculture is facing. Due to this, farmers should be aware of this problem and the necessity of implementing conservation measures. Hence, this study assesses farm households' willingness to participate in soil conservation practice through a Contingent Valuation method in one of the most degraded parts of the country. Double Bounded Dichotomous choice with an Open-ended follow up format was used to elicit the households' willingness to pay using data collected from randomly selected 140 sample households. Results show that the mean willingness to participate in soil conservation practices was about 25 person days per annum and the total aggregate value of soil conservation was computed to be at 975622.73 person days (24390568.3 Birr). Moreover, the Tobit regression model results indicate that the education level of the household head, initial-bid, income, labour shortage and number of days on holiday and social ceremony were important factors influencing the willingness to participate in soil conservation practices. Hence, to improve the participation level, policy should target on supporting adult education, introducing ways to increase farm income and creating awareness on the loss associated with too many days of social ceremonies.
\end{abstract}

Keywords: CVM, Tobit model, soil conservation practices, willingness to pay JEL: Q18, Q24, Q51, Q57

\section{INTRODUCTION}

There is a strong relationship between natural resources and rural livelihoods as healthy land ecosystem is crucial to sustainable development (Von Braun et al. 2013). These resources provide social, economic and ecological functions and services to the existing society (Gessesse et al., 2014). From the record of human achievements, history tells us that civilization and soil fertility are closely interlinked. However, today land degradation is almost universally recognized as a serious threat to human wellbeing (Akter and Gathala, 2014).

Land degradation is defined as a persistent reduction of the land's biological and/or economic production capacity (Safriel, 2007; Vogt et al., 2011). Globally, it is estimated that about a quarter of used land is degraded (Lal et al., 2012) with consequences for more than 2.5 billion people (GEF, 2010). This worldwide depletion of land resources continues to be a serious hazard, particularly, in the developing countries, where agriculture is the main pillar of their economy (Brüntrup and Zimmermann, 2009). For instance, in Sub Saharan Africa, crop production growth lags behind population growth (Diao et al., 2010) and poor soils and nutrient depletion are described as the root cause of declining per capita food production in the region (Mbaga-Semgalawe and Folmer, 2000;Christiaensen and Demery 2007; Kassie et al., 2008).

Soil erosion has both on-site and off-site effects including soil and nutrient loss (Ramos and Marti'nez-
Casasnovas, 2004), long-term productivity loss (Alfsen et al., 1996) and a wide range of environmental problems (Verstraeten et al., 2003). Meanwhile, the immediate consequence of land degradation is a crop yield reduction followed by economic decline and social stress. In general, environmental damage can impede development in two ways. First, it reduces the level of welfare of the society by depleting the environmental resources and then, it reduces long-term productivity and thereby the future earnings. This integrated process of land degradation and increased poverty has been referred to as the "downhill spiral of unsustainably" leading to the “poverty traps” (Greenland et al., 1994).

In Ethiopia, agriculture accounts for about half of GDP, $90 \%$ of exports, and $85 \%$ of total employment (EEA, 2012). Currently, however, the sector is seriously eroded by unsustainable land management practices (Bekele and Drake, 2003; Kassie et al., 2009). Research conducted in various parts of the country (e.g. Taddese, 2001; Bewket and Sterk, 2002; Sonneveld and Keyzer, 2002; Gebremedhin and Swinton, 2003; Yesuf et al., 2005; Amsalu and de Graaff, 2006) showed that land degradation has occurred widely in the country. The Country's inherently fragile soils, undulating terrain, highly erosive rainfall and the environmentally destructive farming methods that many farmers practice coupled with high population density make it highly vulnerable to soil erosion (Tesfaye et al., 2014). 
In agriculture-based poor economy with fast growing populations (the population of the country is increasing nearly by $3 \%$ annually (UNDP, 2009)), degradation of natural resources poses a serious threat to both current and future food production potential. According to Taddese (2001), the country loses annually 1.5 billion metric tons of topsoil from the highlands by erosion, which could have added about 1 to 1.5 million metric tons of grain.

In addition to its impact on agricultural production and productivity, land degradation has far-reaching economic, political, social and environmental implications (Ananda and Herath, 2003). As pointed out by Hurni (1993) land degradation was among the vital factors that led to the decline of the civilizations of Lalibela in the $14^{\text {th }}$ century, of Gondar in the $17^{\text {th }}$ century and more recently, the downfall of the Haile-Selassie Regime. Natural and environmental resource conservation in Ethiopia is therefore not only related to the improvement of ecological environment, but also to the sustainable development of its economy (Teklewold and Kohlin, 2011).

In the country, however, farmers' investments in land management are quite limited (Haregeweyn et al., 2015) and the country still loses a tremendous amount of fertile topsoil.

In Ethiopia, studies related to land degradation have been mainly concentrated in the highlands and it is scanty in other parts of the country (Descheemaeker et al., 2006). However, farmers' perceptions of land degradation and their reactions to perceived degradation vary from place to place and from household to household due to variations in socio-cultural, economic and biophysical conditions (Nederlof and Dangbegnon, 2007). Therefore, it is questionable if results from elsewhere are applicable to the Central rift valley of Ethiopia (CRV).

The CRV is one of the most environmentally vulnerable areas in the country. Households living in the area are faced with erratic rainfall, recurrent droughts, rapid population growth, deforestation, soil degradation, food insecurity and low education (Garedew et al., 2009). Since the area is a closed basin, relatively small changes in land and water use can have far-reaching consequences for the ecosystem (Ayenew, 2004). Generally, excessive land degradation, deforestation and over-irrigation are the features of the area (Legesse et al., 2004; Legesse and Ayenew, 2006).

As Napier et al. (2008) noted, unless the attitudes of all stakeholders in a concerned area are assessed and represented, conservation efforts might not achieve its anticipated outcomes. So far, conservation practices have mainly been undertaken in a form of campaign and quite often farmers have not been involved in the planning process (Asrat et al., 2004). The exclusion of communities from conservation ultimately leads to social conflict and noncompliance with conservation-related regulations (Robbins et al., 2006). Therefore, it is important to recognize local communities as central to the sustainability of land conservation activities as they are the primary beneficiaries and losers otherwise. Thus, this study has assessed the willingness of the communities to participate in the soil conservation activities by applying a contingent valuation technique and the determinants of willingness to pay to stop or reduce the negative effects of soil erosion in the study area.

\section{METHODOLOGY}

\section{Theoretical Framework of Environmental Valuation}

This section deals with the economic theory that helps to obtain measures of consumer benefits from stated preference methodology. Any economic valuation of environment aiming at addressing the question whether or not a given household is better off after changes in environmental quality caused by a given intervention has to follow two steps. First, individual welfare changes of all people potentially affected by the intervention in question have to be assessed and, second, these individual welfare changes have to be aggregated in order to compute the resulting change in social welfare (Ahlheim et al., 2010). The individual welfare change can be measured from simple random utility theory following $\mathbf{Y u}$ and Abler (2010). If the indirect utility function for a respondent is given by, $V\left(p, q^{*}, l\right)$ given labour endowment of the household $l$, soil conservation quality $\mathrm{q}^{*}$ and an exogenous price vectors $\mathrm{p}$. If the respondent decides not to protest and participate in bidding, and she/he is willing to contribute some labour $t(t \geq 0)$ for improving soil conservation quality (e), the indirect utility function can be represented by $V\left(p, q^{*}+e, l-t\right)$. Under the market equilibrium, the indirect utility function becomes (Eq. 1);

$V\left(p, q^{*}, l\right)=V\left(p, q^{*}+e, l-t\right)$

Suppose soil conservation improvement and labour changes are very small, and we can take the first order approximation of Eq.2.

$$
\begin{aligned}
& V\left(p, q^{*}+e, l-t\right) \approx V\left(p, q^{*}, l\right)+\frac{\partial V\left(p, q^{*}, l\right)}{\partial q^{*}} e- \\
& \frac{\partial V\left(p, q^{*}, l\right)}{\partial l} t
\end{aligned}
$$

Combining Equation (1) and (2), we have Eq. 3.

$$
W T P=t=\frac{\partial v\left(p, q^{*}, l\right) / \partial q^{*}}{\partial v\left(p, q^{*}, l\right) / \partial l} e
$$

Equation (3) indicates that WTP may be zero for some person when his/her marginal utility of soil conservation quality $\partial v\left(p, q^{*}, l\right) / \partial q^{*}$ is zero, or when the marginal utility of labour endowment $\partial v\left(p, q^{*}, l\right) / \alpha l$ tends to infinity; otherwise, it will be a positive number 


\section{Contingent Valuation Method (CVM)}

CVM is a survey-based technique for valuation of nonmarket resources, typically environmental attributes and amenities (Alberini and Kahn, 2009; Cho et al., 2008). It uses a hypothetical market to appraise consumer preferences by directly asking their willingness to pay for changes in the level of environmental goods or services (Carson and Hanemann 2005). Therefore, it is under the direct classification. That is, direct valuation method involves direct estimation of environmental value based on the responses of individuals to the hypothetical valuation questions, and hence it does not depend on market information (AMIII, 2003). It is "contingent”, because people are asked to state their willingness to pay, contingent on a specific hypothetical scenario and description of the environmental service. This method is now ubiquitous (Haab and McConnell, 2002) and it has received increasing attention as a means to estimate option and existence values.

In practice, however, the applicability of the CVM becomes problematic in countries where household incomes are very low. This problem is fundamental in developing countries where labour markets are imperfect and disposable incomes are low (O’Garra et al., 2009). Using monetary measures in those countries valuation studies leads to a high number of zero bids resulting from severe financial constraints (Godwin et al., 2011). Hence, payment vehicles play a crucial role in CV studies. Therefore, in developing countries other measuring units than money, especially the labour contribution is suggested for the valuation of public goods (Hung et al., 2007, Asquith et al., 2008). In this case, instead of asking people how much money they would be willing to give up to obtain a certain public good they are will be asked how many working days they would be willing to contribute to the provision of that good (Ahlheim et al., 2010).

In CVM surveys, there are four major elicitation methods. These are: the bidding game, payment card, take-it-or-leave it approach (single bounded dichotomous choice) and take-it-or-leave- it with follow up (doublebounded dichotomous choice). In open-ended question, respondents are asked to state their maximum WTP for the amenity to be valued and no amounts are given beforehand. In bidding game question format, individuals are iteratively asked whether they would be willing to pay a certain amount or not. The amounts are raised (or lowered) depending on whether the respondent was (was not) willing to pay the previously offered amount. It ends when the iterations have converged to a point estimate of WTP. This approach, however, has its own disadvantages. It results in a starting point bias as the final value is systematically related to the initial bid value. Annoying or tiring respondents that cause them to answer yes or no to a stated amount in hopes of terminating the interview is another disadvantage of the bidding game approach. In payment card question, individuals are asked to choose a WTP point estimate from a list of values predetermined by the surveyors, and shown to the respondent on a card. This approach is also criticized on the ground that the respondents might limit their announced WTP to the values listed on the card.
Dichotomous asks simple yes or no questions like: Would you be willing to pay $\$ x$ ? The dichotomous choice approach has become the presumptive method of elicitation for CV practitioners. This method is generally preferred to asking an open-ended question about willingness to pay (Watson and Ryan, 2007).

Many CV studies rely on single bound dichotomous choice approach in which respondents are asked whether they would accept a randomly assigned predetermined single bid amount. The single bounded dichotomous choice format is easier for respondents to make decisions than open-ended questions. However, this method can be highly statistically inefficient (Cameron and Quiggin, 1994). The double-bounded dichotomous choice format is useful to correct the strategic bias and improve statistical efficiency over single-bounded. This method is more efficient than single bounded dichotomous choice as more information is elicited about each respondent's WTP (Arrow et al., 1993). According to (Haab and McConnell, 2002), the yes-yes, no-no response in the double bound dichotomous choice format sharpens the true and makes clear bounds on unobservable true WTP. The dichotomous format gained considerable acceptance because of its incentive compatibility and its substantial simplification of the cognitive task faced by respondents. This paper uses the double-bounded CV followed by an open-ended question. This will help to compare the results obtained from the different elicitation methods. Double-bounded dichotomous method is not free from critics and the followings are biases identified in CVM studies.

Starting point bias: occurs when the respondent's WTP is influenced by the initial value suggested. It may arise if the good being valued is not well defined or the respondent may think the true value for the service to be around the starting point (Boyle and Bishop, 1985). Compliance bias: occurs when the interviewer is leading the respondent towards the answer he/she is expecting. This bias can be reduced by carefully designing the survey, good training of the interviewers and good supervision of the main survey (Mitchell and Carson, 1989). Strategic bias: arises when the respondents expect something out of the result of the study and report not their real WTP but something that they think will affect the research outcome in favour of them. Giving a detailed description of the good being valued and the whole purpose of the study can reduce this bias. Hypothetical bias: If respondents are not familiar with the scenario presented, their response cannot be taken as their real WTP. This bias can be minimized by a careful description of the good under consideration for the respondents. Part-whole bias: occurs when the respondent fails to distinguish between the parts of the good being evaluated and the total group of the goods into which that part falls. All the above-mentioned biases can be minimized by a careful designing of the survey, proper training of the interviewer, conducting a pilot survey and monitoring and supervision of the main survey. All these measures have been taken to minimize the potential impacts of the above biases on the result of this study. 


\section{Estimation of Factors Affecting Willingness to Pay Model}

The zero bid phenomenon is very common in contingent valuation studies (Goodwin et al., 1993). Regression analysis using ordinary least squares for such data is known to lead to biased and inconsistent parameter estimates given the censored nature of the data (Greene, 2003). This nature of the data prompted the use of a Tobit model, which yields consistent and asymptotically normal maximum likelihood estimators of parameters (Kennedy, 2003). The underlying latent regression used in the Tobit model is presented in the Equation 4.

$$
M W T P_{i}^{*}=\beta^{\prime} X_{i}+v_{i}
$$$$
M W T P_{i}^{*}=\left\{\begin{array}{l}
M W T P_{i}^{*} \text { if } M W T P_{i}^{*}>0 \\
0 i f M W T P_{i}^{*} \leq 0
\end{array}\right.
$$

Where, $M W T P_{\mathrm{i}}^{*}$ represents latent willingness to pay in labour for soil conservation practices. $M W T P_{\mathrm{i}}$ is household's maximum willingness to pay in labour for soil conservation practices in a year. $X_{\mathrm{i}}$ is vector of independent variables that are hypothesized to influence maximum willingness to contribute. $B$ is unknown parameter vector to be estimated. $v_{i}$ is error term which are assumed to be normally distributed with mean zero and constant variance. The model parameters are estimated by maximizing the Tobit likelihood function of the Eq. 5 form.

$$
L=\prod_{M W T P^{*}>0} \frac{1}{\sigma} f\left(\ln \left(\frac{M W T P_{i}-\beta X}{\sigma}\right)\right) \prod_{M W T P^{*} \leq 0^{*}} \frac{1}{\sigma} F\left(\frac{-\beta X}{\sigma}\right)
$$

Where, $f$ and $F$ are the density probability function and cumulative distribution function of $\mathrm{MWTP}_{\mathrm{i}}^{*}$ respectively;

$$
\prod_{M W T P^{*}>0} \text { Mean the product over I for which } M W T P^{*}>0
$$
and

$$
\prod_{M W T P^{*} \leq 0^{*}} \text { Mean the product over I for which } M W T P^{*} \leq 0
$$

The regression coefficients of the Tobit regression model cannot be interpreted like traditional regression coefficients that give the magnitude of the marginal effects of change in the explanatory variables on the expected value of the dependent variable. In a Tobit model, each marginal effect includes both the influence of explanatory variables on the probability of dependent variable to fall in the uncensored part of the distribution and on the expected value of the dependent variable conditional on it being larger than the lower bound. Thus, the total marginal effect takes into account that a change in explanatory variable will have a simultaneous effect on the probability of being willingness to participate in soil conservation and the amount of their contribution. McDonald and Moffitt (1980) proposed a useful decomposition of marginal effects that was extended by Gould et al. (1989).
The effect of a given explanatory variable on the probability of WTP is:

$$
\frac{\partial F(Z)}{\partial X_{i}}=f(Z) \frac{\beta_{i}}{\sigma}
$$

The marginal effect of an explanatory variable on the expected value of the dependent variable is:

$\frac{\partial E\left(M W T p_{i}\right)}{\partial X_{i}}=F(\mathrm{Z}) \beta_{i}$ Where $\frac{\beta_{i} X_{i}}{\sigma}$ is denoted by $\mathrm{Z}$ following (Maddala, 1997)

The change in the amount of respondents is willing to pay with respect to a change in explanatory variable among individuals who are willing to pay is:

$$
\frac{\partial E\left(M W T P_{i} / M W T P_{i}^{*}>0\right)}{\partial X_{i}}=\beta_{i}\left[1-Z \frac{f(Z)}{F(Z)}-\left(\frac{f(Z)}{F(Z)}\right)^{2}\right]
$$

Whereas: $F(z)$ is the cumulative normal distribution of $\mathrm{Z}, \mathrm{f}(\mathrm{z})$ is the value of the derivative of the normal curve at a given point, $\mathrm{Z}$ is the $\mathrm{z}$-score for the area under normal curve, $\beta$ is a vector of Tobit maximum likelihood estimates and $\sigma$ is the standard error of the error term.

\section{Description of the Study Area}

This study was undertaken in the Central Rift Valley Ethiopia, explicitly in Arsi-Negele district. Geographically, the district is situated in the Ethiopian central rift valley at $7^{0} 09^{\prime}-7^{0} 41^{\prime} \mathrm{N}$ and $38^{0} 25^{\prime}-38^{0} 54^{\prime}$. Except for the South eastern part, most of the district's elevation is between 1500 and 2300 meters. The major rift valley lakes of Abijata, Langano and Shalla are partly in Arsi Negelle accounting for about 32\% of the total area of the district. The study area covers three agro-ecological zones (low, mid and high land) based on temperature, rainfall, altitude and vegetation (ICRA, 2002). The temperature of the area ranges from $16^{\circ} \mathrm{C}$ to $25^{\circ} \mathrm{C}$ and annual rainfall ranges between $500-1150 \mathrm{~mm}$. The area has relatively fair agricultural potential, which is reflected in the diversity of crops and animal resources. The main crops grown in the area include wheat, maize, teff, barley, sorghum, onion and potato. Annual crops accounted for $95 \%$ of all croplands in the district. The rainfall of the area is a bimodal, with short rain occurring from February to April and the main rain from June to October. The short rain allows farmers to grow potato early and later replace by small cereals specifically wheat. Livestock are also an important component of the farming system in the district.

\section{Sampling design and Method of data collection}

In this study, a two stage random sampling technique was used to select sample households. In the first stage, three kebeles were selected randomly. In the second stage, 140 sample farmers were selected using simple random sampling technique from each kebeles proportional to the total number of households of each kebele. The data for the study were collected through questionnaire using face-to-face interview of the sample 
households. The structured questionnaire had questions related to the demographic, social, institutional, economic, awareness, and willingness to pay for soil conservation practices. The questionnaire also contains the valuation scenario. The scenario tries to give as much information as possible for the respondent about the hypothetical market. Important points, which are suggested by Mitchell and Carson (1989) and Arrow et al (1993) to be considered in the scenario are incorporated as much as possible. Prior to data collection training was given to the enumerators on method of data collection and interviewing techniques.

\section{RESULTS AND DISCUSSION}

\section{General Characteristics of Respondent}

Before embarking on presenting and discussing the results obtained from the econometric models, it is essential to describe the socioeconomic, demographic and institutional variables. Accordingly, the descriptive results are presented in Table 1 and 2. As indicated in Table 2, 92.1\% of the sample households were maleheaded. Since the research area is a rural area, it is not surprising that the educational level is very low, with the average educational level of grade four (Table, 2). The mean age of the sample farmers was about 42 years with a range of 22 to 70 years and the majority of the household heads (48.6\%) were found in the age ranges of 36 and 50 years. The family size ranged from one to 13 with a mean of 5.69 persons per household (Table, 1 ). Around $40 \%$ of sample households had more than six family members.

Table 1. Descriptive statistics of sample households (continuous variables)

\begin{tabular}{lrrrr}
\hline Variable & Mean & Std. Dev. & Min & Max \\
\hline Age & 42.4 & 11. & 22 & 70 \\
Education & 4.2 & 3.4 & 0 & 12 \\
Family Size & 5.7 & 2.2 & 1 & 13 \\
Experience & 20.3 & 10.5 & 3 & 50 \\
Land holding & 1.8 & 1.2 & 0.5 & 4.3 \\
Livestock (TLU) & 7.9 & 9.7 & 0 & 81.1 \\
Extension contact & 42.9 & 14.4 & 12 & 52 \\
Market Distance & 3.8 & 1.9 & 0.1 & 9 \\
Plot to home distance & 1.1 & 0.9 & 0.01 & 5 \\
Income & 17170.9 & 10816.7 & 950 & 39649 \\
Off- day & 6.4 & 2.9 & 0 & 17 \\
\hline Source: Computed from the survey data & & &
\end{tabular}

The minimum land holding in the study area was 0.50 ha while the maximum size of farmland was 4.25 ha. The mean land owned by the sample farmers was 1.80 ha. About $11 \%$ of the sample farmers owned land not more than 0.5 ha whereas $18 \%$ of the sample farmers had more than two ha of land. Respondent farmers on average owned livestock of 7.9 TLU ranging from zero to 81.1 TLU. Oxen, sheep, goats, horses, donkeys and mules are among the livestock that the farmers own. Among them, oxen were the dominant, as $89.8 \%$ of the farmers owned at least one head of ox with average of 2.4 oxen for the sample farmers with the range of zero to 20 , whereas about $80 \%$ farmers owned at least a cow with the mean of 2.46. From small ruminants, goats were the dominant. About $48 \%$ of the sampled households had at least one head of goat. The average goat holding was 5.8 with a maximum holding of 120 heads. Forty-five percent of the farmers owned sheep and the mean sheep holding was 1.9. Donkey was the dominant from equines with maximum of 10 per household and mean of 1.28 .

Table 2. Descriptive statistics of sample households (Dummy variables)

\begin{tabular}{lcrr}
\hline Variable & & $\begin{array}{l}\text { No. of } \\
\text { respondents }\end{array}$ & Percentage \\
\hline Sex & Male & 129 & 92.1 \\
& Female & 11 & 7.9 \\
Membership & Member & 17 & 12.1 \\
& Not & 123 & 87.9 \\
Credit & Users & 47 & 33.6 \\
& Non-user & 93 & 66.4 \\
Off/non-farm & Participant & 26 & 18.6 \\
activity & Non participant & 114 & 81.4 \\
Availability of & Household with & 32 & 22.9 \\
Labour & labour shortage & & \\
& Household with & 108 & 77.1 \\
& no labour & & \\
\hline Source: Computed from the survey data & &
\end{tabular}

The mean distance of sample farmers' residence from nearest market centre was $3.795 \mathrm{~km}$. The result showed that $33.6 \%$ of sample farmers accessed credit from different sources. All of the sample respondents reported that they received extension services though the frequency of contact differs. About $65 \%$ of respondents have indicated that they had extension contact on weekly basis. The survey indicated that $18.6 \%$ of the respondents were engaged in off/non-farm activities. The main activities were selling of firewood, being hired in other's farm and selling local drink.

\section{The Contingent Valuation Survey Results}

In this study, respondents were asked if they were willing to contribute labour or not to a soil conservation program. They were also asked in an open-ended WTP question format to state the highest number of persondays per year that their household would be willing to contribute to the program. The collected data were then calibrated by dropping protest responses before using in econometric analysis. In the CV literature, reasons other than financial constraint and the good having no value to the respondent are considered as protest responses (Labao et al., 2008). Since counting these respondents as having zero willingness to contribute (WTC) would underestimate the welfare gain from program. Therefore, in the practice of CVM, zero bidders are presented with follow-up questions to ascertain whether they are expressing a protest bid against the valuation or they place no value on the intervention.

Accordingly, among 22 respondents (Tab. 3) who are not interested to supply labour for the program, only one respondent replied that he has interest in the program but he will not contribute labour to the program. This could be considered as free rider and classified as protest responses. Whereas, the remaining $95.5 \%$ of the 
households were not willing to pay because of shortage of labour (40.9\%), unable to work due to age, health or disability (18.1\%)or the intervention have no value for them since they do not observe the problem of soil erosion in their farmland (36.4\%). Therefore, they were categorized as true zero bids. These responses indicate that even if people could be willing to contribute labour, their ability to work prohibit them from expressing their preferences. Therefore, even if labour vehicle instead of money avoids this underlying assumption, in the case of skewed income distribution lack of labour, poor health and/or old age could still limit people from stating their 'true' preferences in labour terms.

Table 3. Reasons for Not be willing to participate

\begin{tabular}{lcr}
\hline $\begin{array}{l}\text { Reasons for not be willing to } \\
\text { participate }\end{array}$ & $\begin{array}{c}\text { No. of } \\
\text { respondents }\end{array}$ & Percentage \\
\hline $\begin{array}{l}\text { Shortage of labour in the } \\
\text { household }\end{array}$ & 9 & 40.9 \\
$\begin{array}{l}\text { I don't observe the problem of } \\
\text { soil erosion in my farm land }\end{array}$ & 8 & 36.4 \\
$\begin{array}{l}\text { Age, health, disability } \\
\text { Others have to work }\end{array}$ & 4 & 18.1 \\
Total & 22 & 4.6 \\
\hline Source: Computed from the survey data & & 100 \\
\hline
\end{tabular}

Three sets of bid that were identified from the pilot survey were used for the study. In the pilot survey, the contributions of 10, 20 and 30 man-days per year were the most frequently observed values, and were used as starting point for the willingness to pay bidding game. Thus, $(10,20,5),(20,40,10)$ and $(30,60,15)$ man-days per year were proportionally distributed to the survey questionnaires. As indicated in Table 4, out of 47 respondents offered 10 man-days per year as initial bid, about 59.6\% accepted both the first and second bid. Whereas, $10.6 \%$ accepted the first bid and rejected the follow up higher bid, $17 \%$ rejected the initial bid and accepted the second lower bid and $12.8 \%$ of the respondents rejected both the first and the second bid.

From the respondents of the 20 man-days per year initial bid, about $17 \%$ accepted both first and second bid, $32 \%$ rejected both bids, $14.9 \%$ accepted the first bid and rejected the follow up higher bid, and the remaining $36.2 \%$ rejected the initial bid and accepted the second lower bid. Likewise, from 47 respondents to whom 30 man-days per year as initial bid, about $23.9 \%$ of them accepted both the initial and the second higher bid. $47.8 \%$ accepted the first bid and rejected the next higher bid $10.9 \%$ rejected the first bid price and accepted the follow up lower bid value and $17.4 \%$ rejected both the first and the second lower bid price.
In Table 5, the joint frequency of discrete responses is presented. It shows 37\% responded "Yes-Yes" for both the first and second bids, $22 \%$ (out of which $15.7 \%$ were non-willing) responded "No-No" for both bids, 21\% responded "Yes-No" and the remaining 20\% responded "No-Yes" (Table 5).

Table 5. Joint frequency of discrete response for labour contribution

\begin{tabular}{lcc}
\hline Joint Response & No. of respondents & Percentage \\
\hline Yes- Yes & 52 & 37 \\
Yes-No & 29 & 21 \\
No-Yes & 28 & 20 \\
No-No & 31 & 22 \\
\hline Source: Computed from the survey data
\end{tabular}

Source: Computed from the survey data

\section{Distribution of Responses based on their Maximum Willingness to Pay (MWTP)}

The level of farmers MWTP is presented in Table 6. The amount of labour that the households would contribute to the proposed project ranges from 0 to 140 person days per year. Among the sample households, $27.8 \%$ of them were willing to participate for not more than 20 man days for the program. On the other hand, about $22 \%$ were willing to contribute labour for more than 20 but less than 30 man-days.

Table 6. Frequency Distribution of the Open Ended Questionnaire Format

\begin{tabular}{lcr}
\hline Number of person days & No. of respondents & Percentage \\
\hline 0 & 22 & 15.7 \\
$1-10$ & 9 & 6.4 \\
$11-20$ & 30 & 21.4 \\
$21-30$ & 13 & 22.1 \\
3140 & 33 & 23.6 \\
$\leq 40$ & 15 & 10.7 \\
Total & 122 & 100 \\
\hline
\end{tabular}

Source: Computed from the survey data

Reasons for the "Maximum Willingness to pay"

Respondents were also asked to point out their major reasons for not to contribute more than what they described as their maximum capacity. From the 118 households who had a positive willingness to pay (Tab. 7), $53.4 \%$ of them revealed that they think, "It worth that amount" as their reason for the maximum amount. The households with a positive willingness to pay who revealed, "Others should participate" were about 22\% and about $24.6 \%$ of the households who had a positive willingness to pay revealed "I could not afford more" as their reason for their maximum willingness to pay.

Table 4. Distribution of responses to double bounded question across the bid sets

\begin{tabular}{lrrrrrrrrrr}
\hline \multirow{2}{*}{ Set of Bids } & \multicolumn{2}{c}{ Yes-Yes } & \multicolumn{2}{c}{ Yes- No } & \multicolumn{2}{c}{ No-Yes } & \multicolumn{3}{c}{ No-No } & \multicolumn{3}{c}{ Total } \\
& $\mathrm{N}$ & $\%$ & $\mathrm{~N}$ & $\%$ & $\mathrm{~N}$ & $\%$ & $\mathrm{~N}$ & $\%$ & $\mathrm{~N}$ & $\%$ \\
\hline$(10,20,40)$ & 28 & 59.6 & 5 & 10.6 & 8 & 17 & 6 & 12.8 & 47 & 100 \\
$(20,40,10)$ & 8 & 17 & 7 & 14.9 & 17 & 36.2 & 15 & 31.9 & 47 & 100 \\
$(30,60,15)$ & 11 & 24 & 22 & 47.8 & 5 & 10.9 & 8 & 17.4 & 46 & 100 \\
\hline
\end{tabular}

Source: Computed from the survey data 
Table 7. Reasons for Maximum Willingness to Pay

\begin{tabular}{llr}
\hline Reason For maximum & No. of & Percentage \\
Willingness to Pay & respondents & 53.4 \\
\hline Do not worth more than this & 63 & 24.6 \\
Do not afford more than this & 29 & 22 \\
Others have participate & 26 &
\end{tabular}

Source: Computed from the survey data

\section{Average Willingness to Pay}

In open-ended question format, the arithmetic mean of maximum willingness to pay is taken as the average willingness to pay. Accordingly, the average number of days that farmers were willing to contribute for soil conservation practices was 25 man-days with maximum of 140-man days per year.

The mean values in each initial bid category were also calculated in the same manner. The mean willingness to pay for households with initial bid of 10man day per year was 20.1 man-days per year and it is 15.4 and 39.9 for the initial bid of 20 and 30 man days per year respectively (Table 8 ). The mean values for starting amounts of 10 and 30 man-days per year were higher than the initial bids but mean values for the 20 man-days per year was lower than the initial bids.

Table 8 Willingnessto pay for the different initial bids

\begin{tabular}{llll}
\hline Initial bids & Min & Max & Mean \\
\hline 10 & 0 & 40 & 20.1 \\
20 & 0 & 45 & 15.4 \\
30 & 0 & 140 & 39.9 \\
\hline \multicolumn{4}{l}{ Source: Computed from the survey data }
\end{tabular}

\section{Determinants of Willingness to Pay for Soil Conservation Practices}

After assessing the level of farmers' willingness to contribute for the program and determining the presence of differences among farmers in their level of contribution, finding out factors causing this disparity among farmers was the next most important step of this study. To see this, MWPT of sample farmers were regressed on factors that were expected to affect the level of their contribution using a Tobit estimation procedure. The Tobit model regression results are presented in Table 9. The result of the model showed that educational level of household head, initial-Bid, income, labour shortage and number of days in holiday and social ceremony were important factors influencing the dependent variable.

Education has positive coefficient and is significant at one percent. This implies that the higher the years of schooling, the greater the Willingness to contribute. This is because educated farmers tend to be better at recognizing the risks associated with soil erosion and hence tend to spend more time on soil conservation. The marginal effect results of the Tobit model indicate that, when education level of the household head increases by one year, it increases the probability of willingness to participate in soil conservation practices by $2.2 \%$. Moreover, an additional increase in education level of a household head increases the willingness to contribute for soil conservation practices by 1.382 person days per year for soil conservation practices among the whole population and 1.809 among the willing only. This is supported by the findings of other studies like (Genene, 2006; Kakumanu et al., 2013 and Chukwuone and Okorji, 2008).

The coefficient of initial bid level is negative and is statistically significant at $10 \%$ that indicates the likelihood of accepting an offered bid amount increases as the bid amount goes down and vice versa which is consistent with the economic theory. The marginal effect results indicate that, when initial bid level increases by one unit, it decreases the probability of willingness to pay for soil conservation practices by $0.4 \%$. Furthermore, an additional increase in initial bid level may decreases willingness to pay for soil conservation practices by 0.281 person days per year for soil conservation practices among the whole population and 0.368 among the willing only.

Total income has a positive and significant effect for WTP. This result is also in line with the basic economic theory, which states that individual's demand for most commodities or services positively related with income level. Our result is inconformity with the studies done by (Bogale, and Urgessa, 2012 and Mesfin, et al., 2011).

Availability of labour was also among significant variables that could determine farmers' willingness to contribute at five percent significance level showing that labour is an important factor in determining willingness to pay for soil conservation practices. This is because any form of soil conservation activity demands labour. In order to undertake the practice, farm households need to take some labour away from their farm activities (Asrat, 2004). The marginal effect results designate that, as a household faces labour shortage, the probability of being willing to participate for soil conservation practices decreases by $13.00 \%$. Furthermore, as a household faces labour shortage, the willingness to contribute for soil conservation practices decreases by 6.663 person days per year among the whole population and 8.923 person days per year among the willing only.

Number of days in holiday and social ceremony affects the willingness to contribute labour for soil conservation practices negatively and significantly at $10 \%$ significance level. This means that too many days celebration of holidays and social ceremonies decreases the time that would have used for regular farming activities and for soil conservation practices. Ultimately, it decreases the willingness and amount of labour contribution for soil conservation practices. The marginal effect results of the Tobit model indicate that, when the household head increases celebrating social ceremony by one day, it decreases the probability of willingness to participate in soil conservation practices by $1.3 \%$. Moreover, a loss of a day by a household head in celebrating holidays and social ceremonies decreases the willingness to contribute for soil conservation practices by 0.821 person days per year for soil conservation practices among the whole population and 1.074 among the willing only.

\section{Aggregation of Benefits}

According to Mitchell and Carson (1989) there are four important issues to be considered regarding sample design and execution in order to have a valid aggregation 
of benefits: population choice bias, sampling frame bias, sample none response bias and sample selection bias. Random sampling method was used in this study using a list of household. Protest zero responses were excluded from the analysis and possibility of protest zeros was accounted in the estimation of the aggregate benefit. Hence, none of the above biases was expected in the analysis. Mean was used as a measure of aggregate value of soil conservation in this study. In Table 10, the aggregate WTP was calculated by multiplying the mean WTP by the total number of households who are expected to have a valid response. Following this, the aggregate WTP for soil conservation practices was computed at 975622.73 person days (24390568.3 Birr).

\section{CONCLUSION AND RECOMMENDATION}

Natural resource degradation in general and soil erosion in particular has great effect on the economies of developing countries to which Ethiopia is not an exception. In Ethiopia, the agriculture sector is currently seriously eroded by unsustainable land management practices resulted in a declining agricultural production and increased poverty and food insecurity. In the country, although efforts have been made to conserve the soil, unless the attitudes of all stakeholders in a concerned area are assessed and represented, conservation efforts might not achieve its anticipated outcomes. The objective of this study was thus, to assess the willingness of the communities to participate in the soil conservation activities by applying a contingent valuation technique and identifying the determinants of the willingness to participate for soil conservation practices in Arsi Negele. In this study, the mean willingness to contribute for soil conservation practices was 25 man-days per year.

The factors that affect the willingness to participate for soil conservation practices were analysed using Tobit regression model. The regression results indicated that education level of the household head and income affects the willingness to contribute for soil conservation practices positively, while the initial-bid, labour shortage and number of days in holiday and social ceremony were important factors influencing the willingness to participate for soil conservation practices negatively. Based on the results of the Tobit regression model, the following recommendations are very relevant for policy makers. This means to improve the overall soil conservation participation level in the community, polices should target on supporting adult education, introducing ways to increase farm income and creating awareness on the loss associated with too many days social ceremonies.

Table 9. Estimates of Tobit regression model for determinants of maximum labour contribution

\begin{tabular}{|c|c|c|c|c|c|c|c|c|}
\hline Variables & Coef. & Std. Err. & $\frac{\partial F(Z)}{\partial X_{i}}$ & Std. Err. & $\frac{\partial E\left(M W T p_{i}\right)}{\partial X_{i}}$ & Std. Err. & $\frac{\partial E\left(M W T P_{i} / M W T P_{i}^{*}>0\right)}{\partial X_{i}}$ & Std. Err. \\
\hline Education & $2.087 * * *$ & 0.622 & $0.022^{* *}$ & 0.007 & $1.382^{* * *}$ & 0.414 & $1.809 * * *$ & 0.538 \\
\hline Family size & -1.411 & 1.002 & -0.015 & 0.011 & -0.935 & 0.665 & -1.223 & 0.869 \\
\hline Cooperative & -0.593 & 5.786 & -0.006 & 0.062 & -0.391 & 3.795 & -0.512 & 4.986 \\
\hline Experience & 0.526 & 0.361 & 0.006 & 0.004 & 0.348 & 0.240 & 0.456 & 0.313 \\
\hline Off/non-farm income & -3.785 & 5.137 & -0.042 & 0.061 & -2.442 & 3.231 & -3.230 & 4.315 \\
\hline Land holding & 0.833 & 2.416 & 0.009 & 0.025 & 0.552 & 1.601 & 0.722 & 2.094 \\
\hline Livestock & 0.045 & 0.280 & 0.000 & 0.003 & 0.030 & 0.185 & 0.039 & 0.242 \\
\hline Extension contact & 0.035 & 0.134 & 0.000 & 0.001 & 0.023 & 0.089 & 0.030 & 0.116 \\
\hline Credit & -1.771 & 4.117 & -0.019 & 0.045 & -1.165 & 2.693 & -1.529 & 3.542 \\
\hline Distance to mkt & 0.330 & 1.024 & 0.003 & 0.011 & 0.218 & 0.678 & 0.286 & 0.887 \\
\hline Home to plot distance & 0.945 & 1.971 & 0.010 & 0.021 & 0.626 & 1.305 & 0.819 & 1.708 \\
\hline Bid1 & $-0.425 *$ & 0.231 & $-0.004 *$ & 0.002 & $-0.281 *$ & 0.153 & $-0.368 *$ & 0.200 \\
\hline Off day & $-1.240 *$ & 0.711 & $-0.013^{*}$ & 0.008 & $-0.821 *$ & 0.472 & $-1.074 *$ & 0.616 \\
\hline Labour shortage & $-10.739 * *$ & 4.558 & $-0.130 * *$ & 0.064 & $-6.663 * *$ & 2.644 & $-8.923 * *$ & 3.597 \\
\hline Income & $6.11 \mathrm{E}-04^{* * *}$ & 1.83E-04 & $6.40 \mathrm{E}-06^{* * *}$ & $0.00 \mathrm{E}-07$ & 4.05E-04*** & $1.20 \mathrm{E}-04$ & $5.29 \mathrm{E}-04 * * *$ & $1.60 \mathrm{E}-04$ \\
\hline Age $^{2}$ & -0.003 & 0.004007 & -0.0000397 & 0.00004 & -0.002508 & 0.00266 & -0.0032818 & 0.00348 \\
\hline
\end{tabular}

Table 10. Average and aggregate benefit measures by site

\begin{tabular}{|c|c|c|c|c|c|}
\hline $\begin{array}{l}\text { Total Households } \\
\text { of the district } \\
(\mathrm{Y})^{1}\end{array}$ & $\begin{array}{l}\text { Expected Households to } \\
\text { have a protest zero }(\mathrm{X})^{2}\end{array}$ & $\begin{array}{l}\text { Expected Households' } \\
\text { with Valid Responses } \\
\qquad(\mathrm{Z})^{3}\end{array}$ & $\begin{array}{l}\text { Mean } \\
\text { WTP }\end{array}$ & $\begin{array}{l}\text { Aggregate } \\
\text { Benefit } \\
\text { (Labour) }\end{array}$ & $\begin{array}{l}\text { Aggregate Benefit (in } \\
\text { monetary term) }\end{array}$ \\
\hline 39,272 & 280.51 & 38,991 & 25.02 & 975622.7 & 24390568.3 \\
\hline \multicolumn{6}{|c|}{${ }^{1}$ The figure is taken from annual report of the Central Statistics Agency of Ethiopia (CSA, 2011); } \\
\hline \multirow{3}{*}{\multicolumn{6}{|c|}{$\begin{array}{l}\text { One }(0.71 \%) \text { out of } 140 \text { sampled households was protest zero. This household has to be excluded from further analysis. So X is the expected } \\
\text { number of households who are expected to protest for the proposed project. It is calculated by multiplying the percentage of sampled protest zero } \\
(0.71 \%) \text { with the total population } 39,272 \text { (Y); } \\
{ }^{3} \text { Is the total households in the study area that are expected to have a valid response (i.e. Y-X); }\end{array}$}} \\
\hline & & & & & \\
\hline & & & & & \\
\hline \multicolumn{6}{|c|}{${ }^{4}$ Is mean multiplied by the number of total households that are expected to have valid response ( $\mathrm{Z}^{*}$ Mean WTP) measured in labour; } \\
\hline \multicolumn{6}{|c|}{5 Is the total aggregate benefit in monetary equivalent in Ethiopian Currency (Birr), which is calculated by multiplying the total labour of the } \\
\hline
\end{tabular}




\section{REFERENCES}

ADMASSIE, Y. (2000). Twenty years to nowhere: property rights, land management and conservation in Ethiopia. Red Sea Pr.

AHLHEIM, M., FRÖR, O., HEINKE, A., DUC, N. M., \& DINH, P. V. (2010). Labour as a utility measure in contingent valuation studies: how good is it really? (No. 13-2010). FZID discussion papers.

AKTER, S., \& GATHALA, M. K. (2014). Adoption of conservation agriculture technology in diversified systems and impact on productivity: evidence from three districts in Bangladesh. In 88th Annual Conference, April 9-11, 2014, AgroParisTech, Paris, France (No. 170529). Agricultural Economics Society.

ALBERINI, A., \& KAHN, J. R. (Eds). (2009). Handbook on contingent valuation. Edward Elgar Publishing.

ALFSEN, K. H., DE FRANCO, M. A., GLOMSRØD, S., \& JOHNSEN, T. (1996).The cost of soil erosion in Nicaragua. Ecological Economics, 16(2), 129-145. DOI: doi:10.1016/0921-8009(95)00083-6

AMIII, F. (2003). The measurement of environmental and resource values: theory and methods. Resources for the Future, Washington DC.

AMSALU, A., \& DE GRAAFF, J. (2006). Farmers' views of soil erosion problems and their conservation knowledge at Beressa watershed, central highlands of Ethiopia. Agriculture and Human Values, 23(1), 99-108. DOI: $10.1007 / \mathrm{s} 10460-005-5872-4$

ANANDA, J, \& HERATH, G. (2003). Soil erosion in developing countries: a socio-economic appraisal. Journal of environmental management, 68(4), 343-353. Doi:10.1016/S0301-4797(03)00082-3

ARROW, K. R., SOLOW, P.R., POTNEY, E.E., LEAMER, R., RADNER, H. AND SCHUMAN, (1993).Report of the NOAA Panel on Contingent Valuation. Federal Register, 58:4601-4614.

ASRAT, P., BELAY, K., \& HAMITO, D. (2004).Determinants of farmers' willingness to pay for soil conservation practices in the southeastern highlands of Ethiopia. Land Degradation \& Development, 15(4), 423-438. DOI: 10.1002/ldr.623

AYENEW, T. (2004).Environmental implications of changes in the levels of lakes in the Ethiopian Rift since 1970. Regional environmental change,4(4), 192-204. DOI: 10.1007/s10113-004-0083-X

BEKELE, W., \& DRAKE, L. (2003). Soil and water conservation decision behaviour of subsistence farmers in the Eastern Highlands of Ethiopia: a case study of the Hunde-Lafto area. Ecological economics, 46(3), 437451. Doi:10.1016/S0921-8009(03)00166-6

BEWKET, W., \& STERK, G. (2002).Farmers' participation in soil and water conservation activities in the Chemoga watershed, Blue Nile basin, Ethiopia. Land Degradation \& Development, 13(3), 189-200. DOI: $10.1002 / \mathrm{ldr} .492$

BOGALE, A., \& URGESSA, B. (2012). Households' Willingness to Pay for Improved Rural Water Service Provision: Application of Contingent Valuation Method in Eastern Ethiopia. Journal of Human Ecology, 38(2), 145-154. ISSN 0970-9274
BOYLE, K. J., \& BISHOP, R. C. (1985). The Total Value Of Wildlife-A Case-Study Involving Endangered Species. In American Journal of Agricultural Economics, 67(5), doi:10.1093/ajae/67.5.1271

BRÜNTRUP, M., \& ZIMMERMANN, R. (2009).Potential Engine for African Growth and the Role of Nepad.In CESifo Forum (p. 23).

CARSON, R. T., \& HANEMANN, W. M. (2005). Contingent valuation. Handbook of environmental economics, 2, 821-936.

CARSON, R. T., FLORES, N. E., \& MEADE, N. F. (2001). Contingent valuation: controversies and evidence. Environmental and resource economics, 19(2), 173-210. ISSN 1573-1502

CAMERON, T. A., \& QUIGGIN, J. (1994). Estimation using contingent valuation data from a" dichotomous choice with follow-up" questionnaire. Journal of environmental economics and management, 27(3), 218234. doi:10.1006/jeem.1994.1035

CHO, S. H., YEN, S. T., BOWKER, J. M., \& NEWMAN, D. H. (2008). Modeling willingness to pay for land conservation easements: treatment of zero and protest bids and application and policy implications. Journal of agricultural and applied economics, 40(01), 267-285. DOI: http://dx.doi.org/10.1017/S1074070800028108

CHRISTIAENSEN, L., DEMERY, L., \& KUHL, J. (2011). The (evolving) role of agriculture in poverty reduction-An empirical perspective. Journal of Development $\quad$ Economics, 96(2), 239-254. doi:10.1016/j.jdeveco.2010.10.006

CHUKWUONE, N. A., \& OKORJI, C. E. (2008). Willingness to pay for systematic management of community forests for conservation of non-timber forest products in Nigeria's rainforest region. In: Dellink, Rob B. and Ruijs, A. (eds.), Economics of Poverty, Environment and Natural-Resource Use, 117-137.

DESCHEEMAEKER, K., NYSSEN, J., POESEN, J., HAILE, M., MUYS, B., RAES, D., JAN M, AND J DECKERS, (2006). Soil and water conservation through forest restoration in exclosures of the Tigray highlands. Journal of the Drylands, 1(2), 118-133.

DIAO, X., HAZELL, P., \& THURLOW, J. (2010).The role of agriculture in African development. World development, 38(10), 1375-1383. DOI: 10.1016/j.worlddev.2009.06.011

EEA (Ethiopian Economic Association), (2012).Annual Report on Ethiopian Economy. Addis Ababa, Ethiopia.

GAREDEW, E., SANDEWALL, M., SÖDERBERG, U. \& CAMPBELL, B. M. (2009).Land-use and land-cover dynamics in the Central Rift Valley of Ethiopia. Environmental management, 44(4), 683-694. DOI: 10.1007/s00267-009-9355-z

GEBREMEDHIN, B., \& SWINTON, S. M. (2003). Investment in soil conservation in northern Ethiopia: the role of land tenure security and public programs. Agricultural Economics, 29(1), 69-84. DOI: 10.1111/j.1574-0862.2003.tb00148.x

GEF (Global Environmental Facility), (2010). Land Degradation Strategy. 
GESSESSE, B., BEWKET, W., \& BRÄUNING, A. (2014). Model-based characterization and monitoring of runoff and soil erosion in response to land use/land cover changes in the Modjo watershed, Ethiopia. Land Degradation \& Development.

GOODWIN, B. K., OFFENBACH, L. A., CABLE, T. T., \& COOK, P. S. (1993). Discrete/continuous contingent valuation of private hunting access in Kansas. Journal of Environmental Management, 39(1), 1-12. doi:10.1006/jema.1993.1049

GOULD, B. W., SAUPE, W. E., \& KLEMME, R. M. (1989). Conservation tillage: the role of farm and operator characteristics and the perception of soil erosion. Land economics, 167-182.

GREENE, W.H., (2003). Econometric analysis. $5^{\text {th }}$ ed. Englewood Cliffs, NJ, USA: Prentice Hall.

GREENLAND, D.J., BOWEEN, G., ESWAREN, H., HOADES, R.R., VALENTIN, C., (1994). Soil, Water and nutrient management research. A new agenda. IB SRAM position paper International Board for Research and management (IB SRAM). Bangkok, Thailand.

HAAB, T. C., \& MCCONNELL, K. E. (2002). Valuing environmental and natural resources: the econometrics of non-market valuation. Edward Elgar Publishing.

HAREGEWEYN, N., TSUNEKAWA, A., NYSSEN, J., POESEN, J., TSUBO, M., MESHESHA, BRIGITTA S, ENYEW A, AND FIREW T (2015). Soil erosion and conservation in Ethiopia A review. Progress in Physical Geography.

http://ppg.sagepub.com/content/early/2015/09/02/030913 3315598725.abstract

HUNG, L. T., LOOMIS, J. B., \& THINH, V. T. (2007). Comparing money and labour payment in contingent valuation: the case of forest fire prevention in Vietnamese context. Journal of International Development, 19(2), 173-185. DOI: 10.1002/jid.1294

HURNI, H., (1993). Land degradation, famine and land resources. Scenarios in Ethiopia. In: Pimental D. (ed), Soil erosion and conservation. Cambridge University Press, Cambridge, UK.

ICRA (International Center for Development Oriented Research in Agriculture), (2002). Food security among households in the different agro ecological zones in Arsi Negele Woreda, Ethiopia.

KASSIE, M., PENDER, J., YESUF, M., KÖHLIN, G., \& MULUGETA, E. (2009).The Role of Soil Conservation on Mean Crop Yield and Variance of Yield-Evidence from the Ethiopian Highlands. Working Papers in Economics 408. EfD DP 08-08

KASSIE,M., MAHMUD YESUF, AND GUNNAR KÖHLIN. (2008). The Role of Production Risk in Sustainable Land- Management Technology Adoption in the Ethiopian Highlands Environment for Development. Discussion Paper Series April 2008 EfD DP 08- 15.

KENNEDY, P., (2003). A guide to econometrics. 5th ed. Malden, MA, USA: Blackwell Publishers.

LABAO, R., FRANCISCO, H., HARDER, D., \& SANTOS, F. I. (2008). Do colored photographs affect willingness to pay responses for endangered species conservation? Environmental and Resource Economics, 40(2), 251-264. DOI 10.1007/s10640-0079151-2
LAL, R., SAFRIEL, U., \& BOER, B. (2012). Zero Net Land Degradation: A New Sustainable Development Goal for Rio+ 20. In A report prepared for the Secretariat of the United Nations Convention to Combat Desertification.

http://www.unccd.int/Lists/SiteDocumentLibrary/secreta riat/2012/Zero\%20Net\%20Land\%20Degradation\%20Re port\%20UNCCD\%20May\%202012\%20background.pdf LAL, R. (2001). Soil degradation by erosion. Land degradation \& development, 12(6), 519-539. DOI: $10.1002 / \mathrm{ldr} .472$

LEGESSE, D., \& AYENEW, T. (2006). Effect of improper water and land resource utilization on the central Main Ethiopian Rift lakes. Quaternary international, 148(1), 8-18. doi:10.1016/j.quaint.2005.11.003

LEGESSE, D., VALLET-COULOMB, C., \& GASSE, F. (2004).Analysis of the hydrological response of a tropical terminal lake, Lake Abiyata (Main Ethiopian Rift Valley) to changes in climate and human activities. Hydrological processes, 18(3), 487-504. DOI: 10.1002/hyp.1334

MADDALA, G.S., 1997, Limited Dependent and Qualitative Variables in Econometrics. Cambridge University Press.

MARTÍNEZ-CASASNOVAS, J. A., \& RAMOS, M. C. (2006). The cost of soil erosion in vineyard fields in the Penedès-Anoia Region (NE Spain). Catena, 68(2), 194199. doi:10.1016/j.catena.2006.04.007

MBAGA-SEMGALAWE, Z., \& FOLMER, H. (2000). Household adoption behaviour of improved soil conservation: the case of the North Pare and West Usambara Mountains of Tanzania. Land use policy, 17(4), 321-336. DOI:10.1016/S02648377(00)00033-8

MCDONALD, J. F., \& MOFFITT, R. A. (1980).The uses of Tobit analysis. The review of economics and statistics, 318-321.

MITCHELL, R. C., \& CARSON, R. T. (1989). Using surveys to value public goods: the contingent valuation method. Resources for the Future.

NAPIER, T. L., McCUTCHEON, K., \& FISH, J. (2008).Factors affecting natural resource conservation investments of residents in the Lower Big Walnut Creek watershed, Ohio. Journal of soil and water conservation, 63(1), 18-28. doi: 10.2489/jswc.63.1.26A

NEDERLOF, E. S., \& DANGBEGNON, C. (2007). Lessons for farmer-oriented research: experiences from a West African soil fertility management project. Agriculture and Human Values, 24(3), 369-387. DOI 10.1007/s10460-007-9066-0

NORRIS, P. E., \& BATIE, S. S. (1987). Virginia farmers' soil conservation decisions: an application of Tobit analysis. Southern Journal of Agricultural Economics, 19(01), 79-90.

O'GARRA, T. (2009). Bequest values for marine resources: how important for indigenous communities in less-developed economies?. Environmental and resource economics, 44(2), 179-202. DOI: 10.1007/s10640-0099279-3

PLACE, F., PENDER, J., \& EHUI, S. (2006). Key issues for the sustainable development of smallholder agriculture in the East African highlands. Strategies for 
sustainable land management in the East African highlands, 1-30.

RAMOS, M. C., \& MARTINEZ-CASASNOVAS, J. A. (2004). Nutrient losses from a vineyard soil in Northeastern Spain caused by an extraordinary rainfall event. Catena, 55(1), 79-90. doi:10.1016/S03418162(03)00074-2

ROBBINS, P., MCSWEENEY, K., WAITE, T., \& RICE, J. (2006). Even conservation rules are made to be broken: implications for biodiversity. Environmental Management, 37(2), 162-169. DOI: 10.1007/s00267005-0009-5

SAFRIEL, U. N. (2007).The assessment of global trends in land degradation. In Climate and land degradation (pp. 1-38). Springer Berlin Heidelberg.

SONNEVELD, B. G. J. S., \& KEYZER, M. A. (2003). Land under pressure: soil conservation concerns and opportunities for Ethiopia. Land Degradation \& Development, 14(1), 5-23. DOI: 10.1002/ldr.503

TADDESE, G. (2001). Land degradation: a challenge to Ethiopia. Environmental management, 27(6), 815-824.

DOI: $10.1007 / \mathrm{s} 002670010190$

TEKLEWOLD, H., \& KÖHLIN, G. (2011).Risk preferences as determinants of soil conservation decisions in Ethiopia. Journal of soil and water conservation,66(2), 87-96. doi: 10.2489/jswc.66.2.87

TESFAYE, A., NEGATU, W., BROUWER, R., \& ZAAG, P. (2014). Understanding soil conservation decision of farmers in the Gedeb watershed, Ethiopia. Land Degradation \& Development, 25(1), 7179. DOI: $10.1002 /$ ldr.2187

TILAHUN, M., MATHIJS, E., MUYS, B., VRANKEN, L., DECKERS, J., GEBREGZIABHER, KINDEYA G., AND HANS B.(2011). Contingent valuation analysis of rural households' willingness to pay for frankincense forest conservation. In 2011 International Congress,
Zurich, Switzerland.: European Association of Agricultural Economists.

UNDP (United Nation Development Program), (2009).

Terms of Reference for Consultancy to Carry out Assessment of Past and Present Experiences (Success/ Challenges) On The Resettlement Program In Tigray Region.

VERSTRAETEN, G., POESEN, J., GOVERS, G., GILLIJNS, K., VAN ROMPAEY, A., \& VAN OOST, K. (2003).Integrating science, policy and farmers to reduce soil loss and sediment delivery in Flanders, Belgium. Environmental Science \& Policy, 6(1), 95-103. DOI: 10.1016/S1462-9011(02)00116-8

VOGT, J. V., SAFRIEL, U., VON MALTITZ, G., SOKONA, Y., ZOUGMORE, R., BASTIN, G., \& HILL, J. (2011). Monitoring and assessment of land degradation and desertification: towards new conceptual and integrated approaches. Land Degradation \& Development, 22(2), 150-165. DOI: 10.1002/ldr.1075 VON BRAUN, J., GERBER, N., MIRZABAEV, A., \& NKONYA, E. (2013).The economics of land degradation. ZEF Working Paper 109, Bonn, Germany.

WATSON, V., \& RYAN, M. (2007).Exploring preference anomalies in double bounded contingent valuation. Journal of Health Economics, 26(3), 463-482. doi:10.1016/j.jhealeco.2006.10.009

YESUF, M., MEKONNEN, A., KASSIE, M., \& PENDER, J. (2005). Cost of Land Degradation in Ethiopia: A Critical Review of Past Studies. Environmental Economics Policy Forum in Ethiopia and International Food Policy Research Institute.

YU, X., \& ABLER, D. (2010). Incorporating zero and missing responses into CVM with open-ended bidding: willingness to pay for blue skies in Beijing. Environment and Development Economics, 15(05), 535-556. DOI: http://dx.doi.org/10.1017/S1355770X10000197 